\title{
Development and Validation of the Foreign Language Learning Effort Scale for Turkish Tertiary-Level Students*
}

\author{
Ceyhun Karabıyık ${ }^{1}$ \\ Ufuk University
}

\author{
İsmail Hakkı Mirici ${ }^{2}$ \\ Near East University
}

\begin{abstract}
Current research indicates learning effort to be an important determinant of success in learning, yet the field of education lacks an adequate scale for quantifying foreign language learning effort. The Foreign Language Learning Effort Scale (FLLES) has been developed to measure the effort levels of tertiary-level foreign language learners. Data was collected from students learning English at various public and foundation universities in Ankara in Turkey. An item-pool was initially created and expert opinion was taken to ensure content validity. Next, exploratory factor analysis was carried out over 628 students, which yielded a 4-factor model that was then tested for construct validity and verified using confirmatory factor analyses over both the pilot sample and an independent sample consisting of 701 participants. The internal consistency and reliability coefficients for FLLES and its dimensions were calculated for both the pilot and replication samples. In addition, a test-retest reliability analysis was carried out over 64 students. The scale was further assessed for predictive, convergent, and discriminant validities. The results of the research show the FLLES to be a valid and reliable instrument consisting of 17 items and four dimensions.
\end{abstract}

\section{Keywords}

Effort $\bullet$ Learning effort $\bullet$ Foreign language learning effort $\bullet$ Higher education $\bullet$ Students $\bullet$ Scale development

\footnotetext{
* This article is based on the corresponding author's doctoral thesis at Hacettepe University.

1 Correspondence to: Ceyhun Karabiyı (PhD), Faculty of Education, Ufuk University, Ankara Turkey. Email: ceyhun.karabiyik@ufuk.edu.tr

2 Atatürk Faculty of Education, Near East University, Nicosia, Turkish Republic of Northern Cyprus. Email: hakkimirici@gmail.com

Citation: Katabiyık, C., \& Mirici, İ. H. (2018). Development and validation of the foreign language learning effort scale for Turkish tertiary-level students. Educational Sciences: Theory \& Practice, 18, 373-395. http://dx.doi.org/10.12738/estp.2018.2.0010
} 
Effort is an important and widely-used construct in educational research yet lacks a well-established, clear-cut, and universally-accepted definition. Nevertheless, the construct does have several definitions prevalent in the literature. Soper (1976) defined learning effort as the efficiency with which a student uses one's human capital in a course. A wide set of definitions formulated over the years postulate learning effort as energy spent in the course of learning (Pintrich, Smith, Garcia, \& McKeachie, 1993), in the process of studying (Zimmerman \& Risemberg, 1997), in fulfilling the formal academic demands of one's teacher (Carbonaro, 2005), and in responding to a learning situation (Buenz \& Merril, 1968). Other sets of definitions operationalize learning effort as the amount of study- or course-related work performed (Schuman, Walsh, Olson, \& Etheridge, 1985); the will to commit to onerous situations and be open to unfamiliar and unique challenges (Richter, Lehrl, \& Weinert, 2016); the amount of work performed for learning (Schau, Stevens, Dauphinee, \& Del Vecchio, 1995); the set of behaviors students engage in to master a skill or complete a task (Bozick \& Dempsey, 2010); the actions taken by students in improving their skills (Utami, 2015); sustained actions for completing academic tasks (Kuh, 2001); students' reinvigorated, avid, emotionally-positive, and focused interactions with learning activities (Kindermann, 2007); level of studying (Schuman et al., 1985); and participation in learning/school matters (Johnson, Crosnoe, \& Elder, Jr., 2001).

Foreign language learning effort (FLLE), which is herein defined as the amount of individual resources students invest in the act of learning a foreign language and characterized by in-class and out-of-class endeavors in which students engage to fulfill the process of learning a foreign language, is a notable construct and argued as a facet of motivation Gardner (2001). In his brief and to the point description of motivation, Gardner (2001) points out that while people desire to be successful and attain related rewards, such goals cannot be achieved without expending effort toward them. According to (Gardner, 2001), attitudes toward learning a foreign language and integration together foster the motivation by which motivated individuals engage in foreign language learning behaviors. In their process model of L2 motivation, Dörnyei and Otto (1998) also provided an extensive account of how desires are transformed into goals, goals into intentions, and intentions into actions, as well as how these actions are evaluated for future practices. In this framework, action equates to foreign language effort and becomes realized once motivation towards a desired end is intensified. This is what actualizes a wish, desire, and/or hope. Therefore, one can argue FLLE to be composed of motivated acts geared towards learning a non-native language.

Moreover, foreign language learning effort is also a variable of individual decision (Al Shaye, Yeung, \& Suliman, R. 2014; Heider, 1958; Kuehn \& Landeras, 2013; Rosenbaum, 1972; Weiner, 1985, 1992, 2005; Yeung, 2011) or in other words an autonomous act. According to Deci and Ryan (1985), autonomy, the aspiration to be self-initiating and 
self-regulative regarding personal actions, is an intrinsic human need. For this reason, self-determination, which is undertaking an activity through unmitigated personal want, choice, or consent (Deci, 1992), is viewed as a prerequisite for any endeavor to be intrinsically fulfilling. According to self-determination theory (Deci \& Ryan, 1985), FLLE is considered a self-determined act. According to Paris and Turner (1994, p. 22), the earmark of such an endeavor is one's "ability to choose among alternative courses of action, or at least to choose to expend varying degrees of effort for a particular purpose."

Two conceptualizations exist that promote understanding in the context of learning effort. The literature has been provided one by Carbonaro (2005) and the other by Bozick and Dempsey (2010). Carbonaro (2005) asserted that learning effort is a goal demanding specific endeavor. In this respect, he argued that students might expend similar levels of effort in fulfilling certain goals or demands but different levels of effort in performing others because of hierarchy, where some may require simple compliance while others extensive commitments. Based on the hierarchical nature of goals and demands to be met in the learning context, Carbonaro (2005) distinguished among three types of effort: rule-oriented, procedural, and intellectual. Rule-oriented effort denotes compliance to the norms and rules of the classroom and school. Examples of such commitments are attending class and behaving appropriately. On the other hand, procedural effort expresses endeavors carried out by students for fulfilling classroom-specific demands. Examples of behaviors for students' procedural efforts include endeavors like in-class participation, assignment completion, and assignment submission. The last and most demanding type of effort in Carbonaro's framework is called intellectual effort. This type of effort involves devotion from the student toward understanding and mastering the course content. Intellectual effort involves more complex endeavors like studying and reviewing.

On the other hand, Bozick and Dempsey (2010) elaborated on learning effort in terms of procedural, substantive, and non-compliant behaviors, as well as distinguishing between general achievement- and task-oriented behaviors. According to them, procedural effort consists of completing tasks, adhering to school and classroom rules, and exerting the minimal amount of effort needed for functioning and advancing in school. Punctuality, homework completion, and in-class attentiveness are examples of such efforts. Substantive effort, however, signifies active involvement in learning. Learning behaviors like working hard at school or devoting extra time to preparing or studying for exams are considered substantive types of effort. Meanwhile, noncompliance reflects behaviors that hinder effort exertion, like misbehaving or daydreaming in class, coming late to class, or not completing assigned homework. The second conceptual dimension identified by these scholars is the distinction between general achievement and task-oriented behaviors related to task specificity. General achievement behaviors are related to efforts put forth to do well in the classroom 
and school, like attendance, paying attention, participating in classroom activities, and turning in homework. On the other hand, task-oriented effort is aimed at specific assignments like seatwork and homework.

As foreign language learning is considered a process requiring personal endeavor (Pace, 1982; Wolters, 1999), the prominence of effort in learning foreign languages is quite explicit. In this respect, Dörnyei (2001) noted that as far as success in foreign language learning is concerned, all students in a foreign language classroom have equal chances at success if they put forth the necessary effort. In the same vein, studies carried out in Ghana (Ampofo \& Osei-Owusu, 2015a, 2015b; Opare \& Dramanu, 2002), Malaysia (Shah \& Ng, 2005), Spain (Aratibel, 2013; Carbonaro, 2005), and Japan (Inagaki, 2014) have all concluded effort and achievement in foreign languages to have a positive relationship.

Given the prominence of effort in foreign language learning, being able to accurately and reliably measure it is important. An examination of the relevant line of literature proves attempts to quantify FLLE have occurred using different measures. For example, Opare and Dramanu (2002) quantified effort in learning English as the number of hours spent after class on a normal day. Carbonaro (2005) designed two teacher-response learning effort scales for $8^{\text {th }}$ and $10^{\text {th }}$ graders consisting respectively of seven and three items. The reliability values for these scales range between .83 and .86 across different academic subjects including English. Shah and Ng (2005) used the motivational intensity subscale of Gardner's (1985) Atitude/Motivation Test Battery composed of 10 items. Even though the researchers did not provide any information regarding the measure's reliability coefficient in their study, Gardner's (1985) original study reported reliability coefficients between .71 and .94. Aratibel (2013) measured students' English effort by the amount of time students spend studying English at home on their own or through private lessons and the amount of input they receive outside the classroom watching movies, reading magazines, or travelling abroad. Inagaki (2014) devised a questionnaire on the amount, duration, and content of learning effort; the internal consistency for all sub-scales ranged between .76 and .94. Ampofo and Osei-Owusu (2015a, 2015b) used a questionnaire they made, but information regarding the number of questions, reliability, and validity was unreported.

As can be seen above, attempts have been made for quantifying FLLE. However, the measures used in this regard seem to have reliability and validity issues. Among the indicators of FLLE, study time has been argued to not be a reliable measure (Natriello \& McDill, 1986). One possible explanation for this was provided by Didia and Hasnat (1998), who asserted that as far as study time is concerned, the quality of the time spent is far more important than the quantity. In this respect, Kormanik (2011) also added that students with different competence levels require different 
amounts of time to undertake the same task and that some students may spend more time on a task due to inattentiveness. Moreover, Schuman (2001) touched on the fact that the reported study time is likely to involve some breaks and distractions. Lastly, Carbonaro (2005) highlighted the fact that higher-track students receive more homework compared to their lower-track peers, which thus makes assessing the effort students put forth through time spent on homework difficult as well. On the other hand, even though motivation is certainly associated with FLLE as it explains individual differences in the levels of effort students exert, as Carbonaro (2005) asserted, this is not identical to effort because students that put forth the same amount of effort may well have different motivations. Therefore, predicting effort solely through the intensity of motivation may well be misleading.

Furthermore, no scale developed to date accounts for the multi-dimensional nature of the FLLE construct (Bozick \& Dempsey, 2010; Carbonaro, 2005). Previously constructed measures of learning effort are single scales that mask the multifaceted nature of the construct. While some scholars have called for the need to construct better measures of learning effort (Huang, 2015; Rau \& Durand, 2000), others have pointed to the scarcity of theoretical and empirical research due to the hardship of measuring effort (Kuehn \& Landeras, 2013). In the same vein, no scale is found to our knowledge to have been designed to measure FLLE as a distinct construct. This can be regarded as an important void in need of filling.

In light of this apparent gap, this research has been put forward to develop a valid and reliable instrument for assessing FLLE strongly grounded on Deci and Ryan's (1985) self-determination theory, Gardner's (1985) theory of language learning motivation, Dörnyei and Otto's (1998) process model of L2 motivation, and the frameworks of learning effort put forth by Carbonaro (2005) and Bozick and Dempsey (2010). To sum up, our efforts in this article report over the development of the FLLES, a student self-report instrument that measures the level of effort students put forth in learning a foreign language. The FLLES is believed to be a practical measure for researchers seeking to investigate effort as a multidimensional construct in the context of foreign language learning.

\section{Method}

\section{Research Design}

This is a descriptive study with the purpose of developing a valid and reliable instrument for assessing tertiary-level Turkish students' FLLE levels. In this regard, the five-step model for scale development suggested by Hinkin $(1998,2005)$ has been adopted as a framework. The study includes item development, questionnaire administration, item reduction, scale evaluation, and replication over an independent sample. 
In addition, the predictive, convergent, and discriminant validity of the scale have been assessed. Predictive validity is defined as the degree to which a measure can predict a variable of interest (Ghiselli, Campbell, \& Zedeck, 1981; Huysamen, 1996). Therefore, the ability of the FLLES to discriminate between successful and unsuccessful students has been assessed. Convergent validity refers to the extent to which apparently related constructs relate to each other in reality (Tavakoli, 2012). A review of the literature reveals a positive moderate-to-high correlation between effort in learning a foreign language and attitudes towards learning a foreign language (Ghenghesh, 2010a; 2010b; Hsu, 2005; Shahbaz \& Liu, 2012). As such, the study assesses the correlation between FLLE and attitudes towards learning a foreign language. Meanwhile, discriminant validity refers to the degree to which constructs that should not be related actually are unrelated (Tavakoli, 2012). Thus, in order to determine the discriminant validity of the FLLES, the correlation between FLLE and amotivation has been assessed, as the literature has posited a negative and low correlation between the two constructs (Atalay, Can, Erdem, \& Müderrisoğlu, 2016; Gao, Podlog, \& Harrison, 2012; Kusurkar, Ten Cate, Vos, Westers, \& Croiset, 2013; Ntoumanis, 2002; Pelletier, Fortier, Vallerand, Tuson, \& Brière, 1995).

Additionally, the scale has been tested for internal consistency and test-retest reliability. Cronbach's alpha coefficients (Cronbach, 1951) have been calculated during the piloting and replication phases. The test-retest reliability has been calculated by administering the developed instrument to the same sample under the assumption that it will generate stable results between the two administrations (DeVon et al., 2007; Trochim, 2001) carried out one month apart.

\section{Sample}

Throughout the development and validation of the FLLES, data was collected from the English preparatory schools of two state (Gazi University and Hacettepe Univesity) and three foundation universities (Atılım University, Ufuk University and the University of the Turkish Aeronautical Association) in Ankara. The institutions were selected using convenience sampling whereas the students were selected using random sampling methodology based on voluntary participation. The pilot sample for the exploratory factor analysis (EFA) includes 628 students from At1lim University $(n=106)$, Gazi University $(n=201)$, Hacettepe University $(n=206)$, and Ufuk Univesity $(n=115)$. Meanwhile, the replication sample for confirmatory factor analysis (CFA) includes 701 students from At1lım University $(n=113)$, Gazi University $(n=221)$, Hacettepe University $(n=235)$, and Ufuk Univesity $(n=$ 132). The sample size can be considered suitable with reference to Kline (1994), who submitted that a sample size comprised of at least 100 subjects is adequate for scale development. On the other hand, the sample for assessing the convergent and 
discriminant validity of the scale consists of 472 students from the University of the Turkish Aeronautical Association. From these 472 students, the top and bottom 20\% achievers, which make up 114 successful and 114 unsuccessful students, constitute the predictive validity sample. Lastly, the test-retest reliability sample of the study includes 64 students from Atılım University.

\section{Measures}

Demographic information form. This form asks students to fill out information regarding their gender, age, and midterm grades.

Amotivation Scale. The Amotivation Scale, a subscale of the Language Learning Orientations Scale of Noels, Pelletier, Clement, and Vallerand (2000), is used to determine the levels of amotivation among Turkish university students studying English as a foreign language. The measure has been proven to be a valid and reliable instrument $(\alpha=.82)$ in assessing amotivation and can be used separately from the original scale (Noels et al., 2000). The instrument consists of three questions and is scored on a 7-point Likert scale ranging from "does not correspond" to "corresponds exactly." Moreover, Cronbach's alpha value for this study is .83 .

Attitudes towards Learning English Scale. The scale developed by Dörnyei (2010) is used in this study to assess the attitude levels of tertiary-level students learning English as a foreign language. The measure is composed of 10 items scored on a 6-point Likert scale ranging from "strongly disagree" to "strongly agree." The reliability coefficient of the original scale is .87 and for this study, .88 .

Foreign Language Learning Effort Scale. The 18-item FLLES developed for this study was administered in the piloting phase. All items were prefaced with the heading "In my foreign language classes..." and scored on a 5-point Likert scale ranging from "never" to "always." The latter analyses include the 17 items that remained on the scale using the same format.

\section{Item Generation and Refinement}

An extensive review of the literature and a student survey $(N=219)$ was conducted to grasp the behaviors that Turkish English preparatory school students regard as FLLEs, and descriptions of FLLEs compared with existing definitions of effort in the context of learning formed the basis for generating a preliminary list of items. The list was composed of 27 items with some item pairs to ensure the most intelligible was retained in the pilot measure. In line with the expert review, nine items were deleted due to item pairs, and the pilot survey was composed of 18 items. In order to receive further feedback regarding the clarity of the scale items and the scaling format, a student focus group was conducted with 10 undergraduate students studying 
foreign languages at Ufuk University Preparatory School. As a result, the scale was determined to have no ambiguous items.

\section{Analysis}

First the responses from the pilot survey were entered into the program SPSS 20 and EFA was carried out to determine the latent structure of the FLLES, as suggested by Field (2009). During EFA, a principle component extraction technique was used, being a more reliable technique (Bryman \& Cramer, 2005). After that, CFA was undertaken using the program AMOS 22, where models were compared to reveal whether the one generated from EFA was the model with the best fit. Next, the reliability of the scale for the pilot sample was assessed using SPSS 20. Then CFA was conducted to test the scale's model fit and to support the factor structure determined from the EFA using an independent sample in AMOS 22. Afterwards, the scale was assessed in terms of internal consistency and test-retest reliability using SPSS 20. For the next step, the predictive, convergent, and discriminant validities of the FLLES were measured using a distinct sample. Analyzing predictive validity involved comparing the top and bottom $20 \%$ achievers using an independent samples t-test in SPSS 20. Meanwhile, Pearson's correlation coefficient was calculated using SPSS 20 to compute the relationship for FLLE with attitudes towards learning a foreign language and amotivation to assess FLLES's convergent and discriminant validities. Lastly, SPSS 20 was used in the scale's reliability analyses for computing the relevant statistics.

\section{Findings}

After generating a preliminary set of items and determining the content validity of the items using an expert panel, the researcher collected data in person upon receiving the ethics committee's approval for the research. Afterwards, the necessary analyses were carried out to determine the factor structure, reliability, and validity of the measure.

\section{Findings of the Exploratory Factor Analysis}

As a first step before the analysis, the negatively worded items were reversed scored in SPSS 20. Next, the sample size was evaluated in order to determine whether the sample is adequate or not to conduct an EFA using the Kaiser-Meyer-Olkin (KMO) statistic which denotes sampling adequacy (Kaiser, 1974). According to Kaiser (1974), values between .00 and .49 are unacceptable, .50 and .59 are miserable, .60 and .69 are mediocre, .70 and .79 are middling, .80 and .89 are meritorious, and .90 and 1 are marvelous. In this research the KMO value for the related sample was .86; indicating a good sample size for the analysis to be conducted (Kaiser, 1974). Next, the skewness, kurtosis, Kolmogorov-Smirnov, and Shapiro-Wilk statistics were calculated and histograms and normal q-q plots were generated to assess the normality of the data. It 
was found that the normality assumptions were not substantially violated and that it could be assumed that the data is normally distributed. Then, the items were checked for multicollinearity and as none of the inter-item correlations were over .90 (Field, 2009), it was determined that the multicollinearity assumption was also satisfied.

Upon checking that the assumptions had been satisfied, exploratory factor analysis was carried out by applying a varimax-type rotation using SPSS 20. The exploratory factor analysis helped refine the item pool as well as allow for testing dimensionality (Churchill, 1979). An analysis of the scree plot, Eigen values, and results from the Monte Carlo PCA for Parallel Analysis over the pilot sample assisted in preliminarily assigning the number of underlying dimensions of FLLE. In line with the suggestions from Kim and Mueller (1978) and Stevens (2002), item-loading thresholds for factors were determined as .40. The initial factor analysis, the scree plot (Figure 1), and the Monte Carlo PCA for Parallel Analysis indicated a 4-factor solution. Items that closely cross loaded, did not load, or did not load above the generally accepted cutoff of .40 were eliminated. In this analysis, one item ("I skip classes") did not load in any of the factors and therefore was eliminated from further analysis.

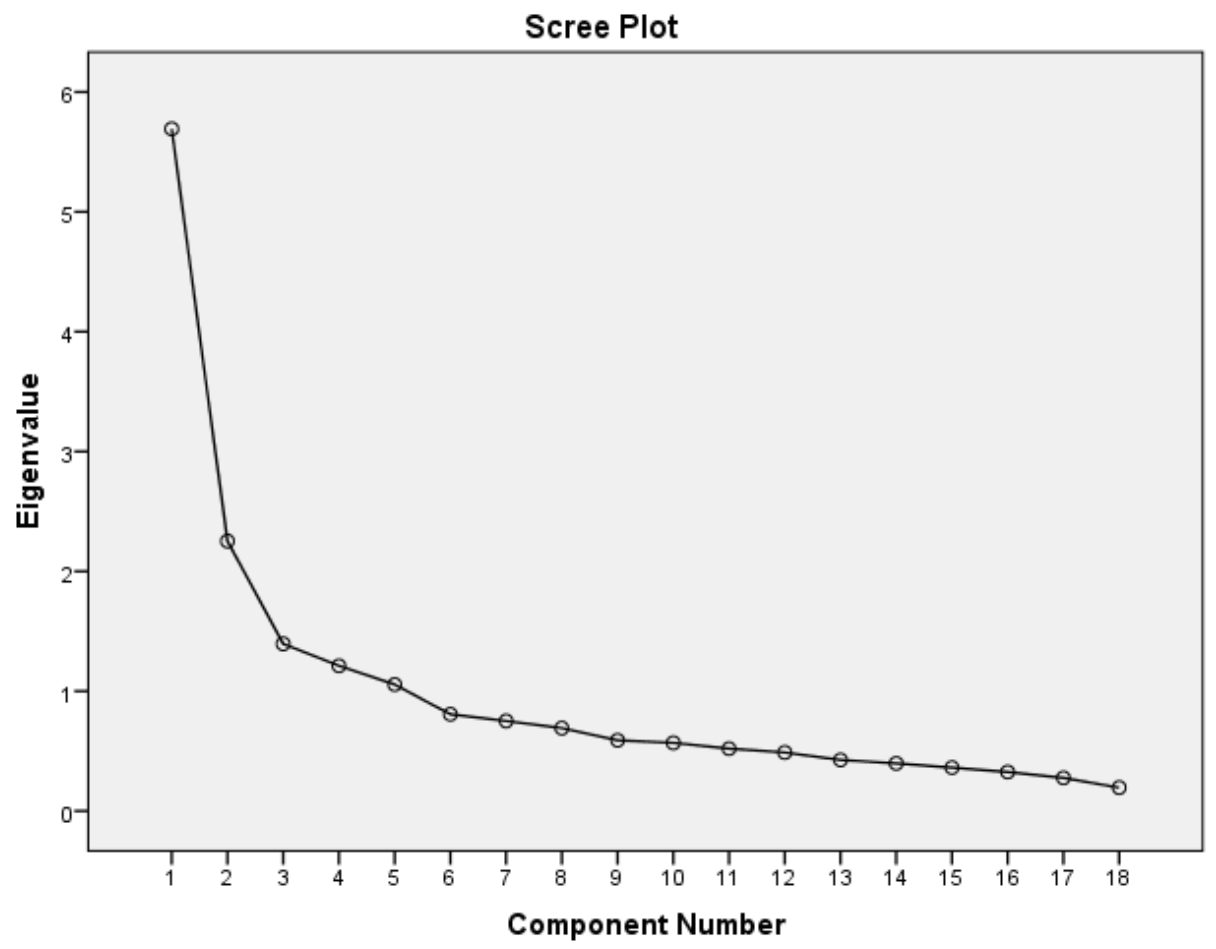

Figure 1. Scree plot. 
When the items in each factor were examined (Table 1), it was found that factor one was comprised of items denoting non-compliance whereas factor two, three and four focused on procedural, substantive and focal types of effort. The factor loads of all items were greater than .40. The first dimension labeled non-compliance contains three items and explained $\% 8.16$ of the total variance. The second dimension labeled procedural effort had three items and explained \% 13.21 of the total variance. The third dimension labeled substantive effort contained eight items and explained \% 32.27 of the total variance. The fourth dimension labeled focal effort had three items and explained $\% 7.13$ of the total variance.

Table 1

Item-Factor Structure of the Foreign Language Learning Effort Scale

\begin{tabular}{|c|c|c|c|c|c|c|}
\hline & & & Factor 1 & Factor 2 & Factor 3 & Factor 4 \\
\hline Items & $M$ & $S D$ & Non-Compliance & Procedural Effort & Substantive Effort & Focal Effort \\
\hline 2 & 4.12 & 1.06 & .85 & & & \\
\hline 8 & 4.24 & 1.12 & .90 & & & \\
\hline 14 & 4.00 & 1.09 & .84 & & & \\
\hline 4 & 3.77 & 1.02 & & .87 & & \\
\hline 10 & 3.99 & .99 & & .89 & & \\
\hline 16 & 4.01 & .91 & & .70 & & \\
\hline 1 & 3.50 & .99 & & & .56 & \\
\hline 3 & 2.91 & 1.08 & & & .64 & \\
\hline 5 & 2.00 & .98 & & & .72 & \\
\hline 7 & 2.56 & 1.15 & & & .77 & \\
\hline 9 & 3.74 & 1.03 & & & .55 & \\
\hline 11 & 3.58 & 1.03 & & & .43 & \\
\hline 13 & 2.95 & 1.16 & & & .60 & . \\
\hline 15 & 2.16 & 1.14 & & & .56 & \\
\hline 6 & 4.03 & .74 & & & & .81 \\
\hline 12 & 3.64 & .89 & & & & .80 \\
\hline 17 & 3.33 & .95 & & & & .69 \\
\hline Eigenvalues & & & 1.39 & 2.25 & 5.49 & 1.21 \\
\hline Explained Variance & & & 8.16 & 13.21 & 32.27 & 7.13 \\
\hline $\begin{array}{l}\text { Random } \\
\text { Eigenvalues by } \\
\text { Mahalanobis PA }\end{array}$ & & & 1.19 & 1.24 & .129 & 1.15 \\
\hline
\end{tabular}

\section{CFA Findings for the Pilot Sample}

CFA was carried out in this phase to compare the four-factor model's fit and confirm the FLLES's construct validity. According to Kline (2016), the minimum set of fit statistics to be reported in terms of this analysis are the model chi-square $\left(\chi^{2}\right)$, degrees of freedom $(d f)$, $p$-value, Root Mean Square Error of Approximation (RMSEA) (Steiger, 1990), Comparative Fit Index (CFI) (Bentler, 1990), and Standardized Root Mean Square Residual (SRMR) (Bentler, 1995). In light of this, the recommended values as well as the Goodness of Fit Index (GFI) (Jöreskog \& 
Sörbom, 1989; Tanaka \& Huba, 1984), Adjusted Goodness of Fit Index (AGFI) (Jöreskog \& Sörbom, 1989), Normed Fit Index (NFI) (Bentler \& Bonnet, 1980), and Non-Formed Fit Index (NNFI) (Bentler \& Bonnet, 1980) values were used to assess model fit. The normed chi-square $\left(\chi^{2} / d f\right)$ was not used, as Kline (2016) proposed it to have a limited statistical or rational foundation and no part in fit testing.

The literature indicates the necessity for a sample size of 20 times the number of parameters (Jackson, 2003; four in our case) or a sample of about 200 participants (Shah \& Goldstein, 2006) for carrying out CFA. The sample size consists of 701 students and, accordingly being considered adequate, the analysis was carried out. The fit indices for the 4-factor model were analyzed and found to be $\chi^{2}=314.40, d f=.110, R M S E A=$ $.05, S R M R=.04, G F I=.95, A G F I=.92, C F I=.95, N F I=.93, N N F I=.94, p=0.00$. According to the parameters of model fit in Table 2 as suggested by Arbuckle \& Wothke (1999), Byrne (2001), Jöreskog \& Sörbom (1993), Kline (1998), and SchermellehEngel \& Moosbruger (2003), the model fit for the 4-factor model is sufficient.

Table 2

\begin{tabular}{lccc}
\hline Parameters of Model Fit & & & \\
\hline Fit Indices & Good Fit & Sufficient Fit & Findings \\
\hline$A G F I$ & $.90 \leq A G F I \leq 1.00$ & $.85 \leq A G F I \leq .90$ & .92 \\
$C F I$ & $.97 \leq C F I \leq 1.00$ & $.95 \leq C F I \leq .97$ & .95 \\
$G F I$ & $.95 \leq G F I \leq 1.00$ & $.90 \leq G F I \leq .95$ & .95 \\
$N F I$ & $.95 \leq N F I \leq 1.00$ & $.90 \leq N F I \leq .95$ & .93 \\
$N N F I$ & $.97 \leq N N F I \leq 1.00$ & $.95 \leq N N F I \leq .97$ & .94 \\
$R M S E A$ & $0 \leq R M S E A \leq .05$ & $.05 \leq R M S E A \leq .08$ & .05 \\
SRMR & $0 \leq S R M R \leq .05$ & $.05 \leq S R M R \leq .10$ & .04 \\
\hline
\end{tabular}

\section{Findings from the Internal Consistency Analysis}

After performing CFA with the pilot sample, assessments of the scale's internal consistencies were carried out. Cronbach's alpha values were calculated for all four subscales. The first dimension of non-compliance has a Cronbach's alpha of .85 . The second dimension of procedural effort has a Cronbach's alpha of .85. The third dimension of substantive effort has a Cronbach's alpha of .81, and the fourth dimension of focal effort has a Cronbach's alpha of .75. Cronbach's alpha value for the scale is .86. The internal consistency analysis results show all alpha values to be sufficient (Cronbach, 1951; George \& Mallery, 2003; Lance, Butts, \& Michels, 2006; Nunnally, 1978).

Analysis of the scale statistics, item variances, and alpha when an item was removed does not show any questionable item except Question 16 in the sub-dimension of procedural effort. Because this scale already has a satisfactory Cronbach's alpha ( $\alpha=$ $.85)$ and deleting one item would only cause a very minor increase in the Cronbach's alpha $(\alpha=.87)$ with a corrected item-total correlation $(r=.63)$ above the 60 threshold (Hair, Black, Babin, \& Anderson, 2010), all items in the dimension of procedural effort were retained. 


\section{Findings from the Replication Study}

The replication procedure is the final step in scale development, and the scale was replicated over an independent sample for this purpose. The sample-size assumption was rechecked, and the sample size consisting of 701 participants was acknowledged as sufficient (Jackson, 2003; Shah \& Goldstein, 2006). Next, the normality and multicollinearity assumptions were checked. After all assumption and normality checks were carried out and the data was found fit for the analyses, the instrument was retested for model fit using CFA over the replication sample through AMOS 22, which is presented in Figure 2. The CFA results $\left(\chi^{2}=275.48, d f=102, R M S E A\right.$ $=.05, G F I=.96, C F I=.96, N N F I=.95, p=0.00)$ show the 4-factor model to also display good fit with the replication sample (Arbuckle \& Wothke, 1999; Byrne, 2001; Jöreskog \& Sörbom, 1993; Kline, 1998; Schermelleh-Engel \& Moosbruger, 2003).

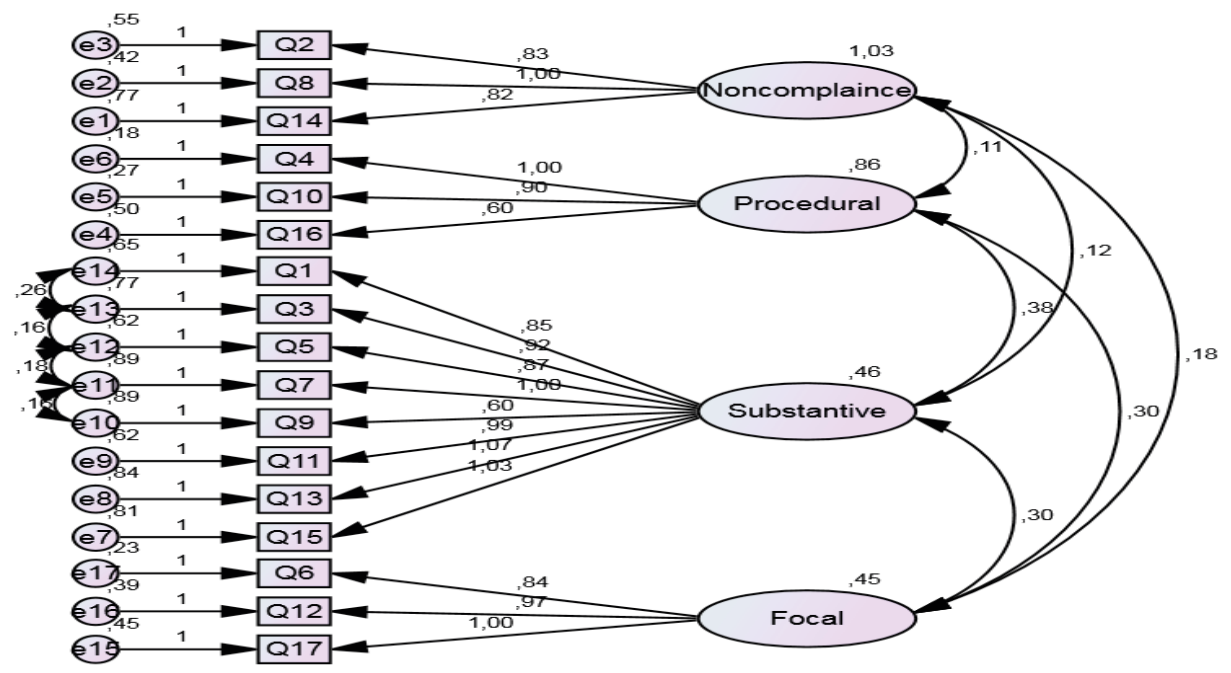

Figure 2. Confirmatory factor analysis carried out over the replication sample.

\section{Findings from the Internal Consistency Analysis}

The internal consistency of the scale for the replication sample was evaluated using the Cronbach's alpha values. The reliabilities of the subscales are $.80, .83, .82$, and .77 for non-compliance, procedural effort, substantive effort, and focal effort, respectively. Cronbach's alpha value for the scale is .85 . The results of the internal consistency analysis prove the FLLES to also show good internal consistency for the replication sample (Cronbach, 1951; George \& Mallery, 2003; Lance et al., 2006; Nunnally, 1978). 


\section{Findings from the Test-Retest Reliability Analysis}

As part of the test-re-test reliability, a total of 64 (21 female and 43 male) students volunteered to take part in the two-step process. All participants are studying at At1lim University, Ankara. The two administrations were carried out one month apart during students' class hours. In order to match the results of the two administrations, the volunteers were asked to write a nickname on the scales they filled out. After collecting the data, they were entered into SPSS 20. The results $(r=.86, n=64, p=0.00)$ of the test-retest reliability show high positive correlations between the two tests (Hinkle, Wiersma, \& Jurs, 2003).

\section{Findings from the Predictive Validity Analysis}

First the suitability of the sample size and normality assumptions for analysis were checked. After determining that the data to be fit, an independent-samples $t$-test was conducted to investigate the differences in the FLLEs of successful and unsuccessful students in order to assess whether the FLLES is able to discriminate between the two groups of learners. Given that no violation of Levene's test of homogeneity of variances was found $\left(F_{(1,226)}=0.81, p=0.78\right)$, the independent $t$-test was calculated assuming $N$ homogeneous variances. The results show a significant difference to exist in the scores of successful $(M=59.40, S D=9.57)$ and unsuccessful $(M=54.24$, $S D=9.22)$ students $\left(t_{(226)}=-4.15, p=0.00\right)$.

\section{Findings from the Convergent and Discriminant Validity Analyses}

The suitability of sample size and normality assumptions for the analyses were checked as a first step. Upon determining the data to be adequate for analysis, Pearson's correlations were calculated for FLLE with attitudes and FLLE with amotivation.

Table 3

Pearson's Correlation Coefficient Regarding the Correlation between FLLE and Attitudes towards Learning English

\begin{tabular}{cc}
\hline Scale & Attitudes \\
\hline Effort & $.73^{* *}$ \\
\hline
\end{tabular}

$N=472,{ }^{* *} p<0.01$

As can be observed from Table 3, a statistically significant, strong, and positive correlation exists between FLLE and attitudes towards learning English $(r=.73, p=0.00)$.

Table 4

Pearson's Correlation Coefficient Regards The Correlation Between FLLE and Amotivation

\begin{tabular}{rc}
\hline Scale & Amotivation \\
\hline Effort & $-.20^{* *}$ \\
\hline$N=472,{ }^{* *} p<0.01$ &
\end{tabular}

An examination of Table 4 shows a statistically significant, weak, and negative correlation between FLLE and amotivation $(r=-.20, p=0.00)$. The results are further elaborated upon in the Discussion. 


\section{Discussion}

The aim of the current study has been to develop an instrument for quantifying the levels of effort expended by tertiary-level Turkish students in learning foreign languages. After a comprehensive process of item development for the FLLES, results from the exploratory factor analysis undertaken for the structural validity of the scale show foreign language learning effort to be a multidimensional construct. The sub-dimensions are named: noncompliance, procedural effort, substantive effort, and focal effort, in line with the related literature. Non-compliance refers to behaviors that hinder exerting effort in the foreign language classroom. This dimension is similar to what Bozick and Dempsey (2010) called "rule-oriented effort," but is distinct from the concept in that it only focuses on classroom behaviors. The second factor is comprised of items that fall in the category of the formerly conceptualized procedural effort (Bozick \& Dempsey, 2010; Carbonaro, 2005) and indicate endeavors engaged in for fulfilling the demands specific to the foreign language classroom. Moreover, items included in the third dimension represent substantive effort, which is related to behaviors that denote active involvement in learning a foreign language. The additional factor of focal effort arose from the analysis and reflects attentiveness in the foreign language classroom, which had been formerly classified under procedural effort by Bozick and Dempsey (2010) and under intellectual effort by Carbonaro (2005). This may have happened because the dimensions of both learning effort models had not been previously empirically analyzed and both conceptualizations had solely been done in light of the literature. However, a review of the related literature proves that many researchers have acknowledged attention and attentiveness as a dimension of effort (Ceballo, McLoyd, \& Toyokawa, 2004; Chao, 2001; Cho, 2015; Cowan, 2005; Finn, Lee, Kraus, \& Hudson Kam, 2014; Idan \& Margalit, 2014; Shouse, Schneider, \& Plank, 1992). Moreover, as argued by Kanfer (1992), effort is both physical and cognitive, and as asserted by many scholars, cognitive effort is the load of attention apportioned to a process, learning English in this context. Therefore, sufficient evidence exists in the literature to argue that FLLE has a focal dimension. All in all and distinct from other measures of learning effort evident in the related line of literature that has omitted the focal aspect of focal effort, the FLLES embodies all characteristics of learning effort in the context of foreign language learning. Moreover, this adds to the evidence that learning effort is indeed a multifaceted construct within the context of foreign language learning.

Additionally, the item-factor structure of the scale is also in line with the related literature. The total variance explained by the 4 -factor model $(60.77 \%)$ is in line with the suggestions from Hair, Black, Babin, Anderson, and Tatham (2014). The factor loadings of the scale's dimensions range between .84 and $.90, .70$ and $.89, .43$ and .77, and .69 and .81; all are above the accepted cut-off point of .40 (Hair, Black, Babin, Anderson, \& Tatham, 2006). Cronbach's alpha values for the scale's four dimensions in the pilot study are $.85, .85, .81$, and .75 , while the coefficient for the entire scale 
is .86. These values indicate the scale to be internally consistent (Cronbach, 1951; George \& Mallery, 2003; Lance et al., 2006; Nunnally, 1978).

Confirmatory factor analysis of the 17-item version reveals acceptable fit for the 4-factor model (see Table 2). Furthermore, the reliability coefficients for the scale over the replication sample have been found as $.80, .83, .82$, and .77 for non-compliance, procedural effort, substantive effort, and focal effort, respectively, with Cronbach's alpha value for the entire scale as .85. All in all, the values prove the FLLES to also demonstrate good internal consistency in the analysis over the replication sample (Cronbach, 1951; George \& Mallery, 2003; Lance et al., 2006; Nunnally, 1978). Furthermore, the scale demonstrates reliability and stability over time as well. The test-retest statistic is above the minimum threshold of .70 (Terwee et al., 2007), showing a .86 correlation between the two administrations of the instrument carried out four weeks apart. In light of the scale's reliability analyses, the FLLES is considered able to be reliably used for measuring the levels of foreign language learning effort expended by Turkish students. Further studies with distinct samples are anticipated to enhance the reliability of the instrument over time.

Distinct from the previous measures for assessing the effort students expend in learning foreign languages, clear validity advantages have been demonstrated for the FLLES. The current measure is able to discriminate between successful and unsuccessful students, demonstrating predictive validity (Ghiselli et al., 1981; Huysamen, 1996; Maroof, 2012). This result, which depicts learning effort as a predictor of achievement in learning foreign languages, is in line with previous findings. For instance, in a study carried out in Ghana, Opare and Dramanu (2002) concluded effort in learning English to have a significant and positive relationship with educational outcomes for junior secondary-school students. In another study, Aratibel (2013) found significant correlations between effort and English achievement for Spanish high school students. The study carried out by Inagaki (2014) over Japanese undergraduate students studying English also revealed that high amounts of effort expended for a long time lead to higher academic outcomes. Moreover, in studies carried out by Ampofo and Osei-Owusu (2015a, 2015b) over public senior high school students in Ghana, positive correlations were also ascertained between effort in learning English and academic performance.

In addition, the positive correlation found between attitudes towards learning a foreign language and FLLE is also in congruence with the findings of previous studies. The studies carried out by Ghenghesh (2010a; 2010b) in the context of Libya revealed attitudes towards English and Arabic to positively correlate $(r=.52$, $r=.41$ ) with learning effort for 7th-10th grade students and 6-10th grade students, respectively. Moreover, in a study carried out over a freshman college sample in 
Pakistan, Shahbaz and Liu (2012) also discovered a positive relationship between attitudes towards learning English and learning effort $(r=.76)$. A lower but still positive association $(r=.34)$ between the two variables was found by Hsu (2005) for sophomore college students studying business English in Taiwan. In total, the positive correlation between attitudes towards learning foreign languages and learning effort is clearly in line with previous research, and this testifies to the fact that the FLLES demonstrates convergent validity (Bagozzi, Yi, \& Phillips, 1991).

Lastly, a negative correlation was determined between participants' FLLES scores and their amotivation levels. This result is also in agreement with previous studies carried out in different educational contexts. In the study carried out by Atalay at al. (2016) over Turkish tertiary-level medical students, amotivation and learning effort were revealed to negatively correlate $(r=-.38)$. Similarly, a negative correlation ( $r=$ -.09) was also found between these two constructs in Kusurkar et al.'s (2013) study that included participants from a medical college in the Netherlands. In another study, Gao et al. (2012) revealed a negative association between effort and amotivation for US college students in physical education classes $(r=-.10)$. In the same vein, Pelletier et al. (1995) found a negative relationship between amotivation and effort for university athletes $(r=-.26)$. Moreover, in a study undertaken at 10 state schools in northwestern England, Ntoumanis (2002) also concluded negative correlations to exist between student effort in PE classes and their amotivation $(r=-.52)$. All in all, the congruent negative correlation found between FLLE and amotivation in this study also provides evidence for the discriminant validity of FLLES (Bagozzi, et al., 1991).

Further research is believed needed for enhancing the evidence related to the measure's reliability and validity. Even though statistically adequate sample sizes have been used in the analyses, the study sample is limited to participants in Ankara, as the convenience sampling methodology was adapted. Replication studies regarding the reliability and validity of the instrument over distinct samples may prove valuable. Moreover, the validity of the instrument can be further tested with variables such as motivation, learner interest, and foreign language learning anxiety. Finally, the study was carried out with students studying at the foreign language preparatory schools of their respective universities, so further validating the instrument over samples of university students studying in their departments may be a sound idea.

\section{Conclusion}

The FLLES has been designed to quantify the effort exerted by tertiary-level students in learning foreign languages. Psychometrically, the scale is reliable, shows sufficient factorial validity, and correlates with measures of related constructs, as expected. Moreover, the utility of the FLLES has been attested to by showing that it 
predicts student success in foreign language learning. Therefore, the FLLES is offered as a competent, reliable, and valid measure of effort in learning foreign languages.

Using FLLES (see Appendix 1), the individual differences in levels of foreign language learning effort and the reasons behind these differences can be explored. Studies can focus on the factors that increase or hinder effort in learning foreign languages. In the same vein, the effects of learning effort in the context of foreign language learning can be investigated. Longitudinal studies in this respect may reveal some interesting findings. Moreover, as this study was carried out over a limited number of tertiary-level foreign language learners, further research on testing the validity and reliability of the scale using more comprehensive and diverse groups of learners is recommended and will further strengthen the validity and reliability of the instrument.

\section{References}

Al Shaye, R., Yeung, A. S., \& Suliman, R. (2014). Saudi female students learning English: Motivation, effort, and anxiety. The International Journal of Learner Diversity and Identities, 20(4), 1-13.

Ampofo, E. T., \& Osei-Owusu, B. (2015a). Determinants of academic performance among senior high school (SHS) students in the Ashanti Mampong municipality of Ghana. International Journal of Academic Research and Reflection, 3(5), 19-35.

Ampofo, E. T., \& Osei-Owusu, B. (2015b). Students' academic performance as mediated by students' academic ambition and effort in the public senior high scjools in Ashanti Mampong Municipality of Ghana. International Journal of Academic Research and Reflection, 3(5), 19-35.

Aratibel, A. P. (2013). The effects of socio-economic background, personal effort, and motivation in English proficiency (Master's thesis, Universidad Publica de Navarra). Retrieved from http:// academica-e.unavarra.es/bitstream/handle/2454/9827/Proyecto_AmaiaPrieto.pdf? sequence=1

Arbuckle, J., \& Wothke, W. (1999). AMOS 4 user's reference guide. Chicago, IL: Smallwaters Corp.

Atalay, K., Can, G., Erdem, Ş., \& Müderrisoğlu, İ. (2016). Assessment of mental workload and academic motivation in medical students. Journal of the Pakistan Medical Association, 66(5), 574-578.

Bagozzi, R. P., Yi, Y., \& Phillips, L. W. (1991). Assessing construct validity in organizational research. Administrative Science Quarterly, 36, 421-458.

Bentler, P. M. (1990). Comparative fit indexes in structural models. Psychological Bulletin, 107, 238-246.

Bentler, P. M. (1995). EQS structural equations program manual. Encino, CA: Multivariate Software.

Bentler, P. M., \& Bonett, D. G. (1980). Significance tests and goodness of fit in the analysis of covariance structures. Psychological Bulletin, 88, 588-606.

Bozick, R. N., \& Dempsey T. L. (2010). Effort. In Rosen, J. A., Glennie, E. J., Dalton, B. W., Lennon, J. M. \& R. N., Bozick (Eds.), Noncognitive skills in the classroom: New perspectives on educational research (pp. 39-68). Research Triangle Park, NC: RTI International.

Bryman, A., \& Cramer, D. (2005). Quantitative data analysis with SPSS12 and 13. A guide for social scientists. East Sussex: Routledge.

Buenz, R. Y., \& Merrill, I. R. (1968). Effects of effort on retention and enjoyment. Journal of Educational Psychology, 58, 154-158. 
Byrne, B. M. (2001). Structural equation modeling with AMOS. Basic concepts, applications, and programming. Mahwah, NJ: Erlbaum.

Carbonaro, W. (2005). Tracking, student effort, and academic achievement. Sociology of Education, $78,27-49$.

Ceballo, R., McLoyd, V. C., \& Toyokawa, T. (2004). The influence of neighborhood quality on adolescents' educational values and school effort. Journal of Adolescent Research, 19(6), 716-739.

Chao, R. K. (2001). Extending research on the consequences of parenting style for Chinese Americans and European Americans. Child Development, 72, 1832-1843.

Cho, M. (2015). The effects of working possible selves on second language performance. Read and Writing, 28, 1099-1118.

Churchill, G. A. (1979). A paradigm for developing better measures of marketing constructs. Journal of Marketing Research, 16, 64-73.

Cowan, N. (2005). Working memory capacity. Hove, East Sussex, UK: Psychology Press.

Cronbach, L. J. (1951). Coefficient alpha and the internal structure of tests. Psychometrika, 16, 297-334.

Deci, E. L. (1992). The relation of interest to the motivation of behavior: A self-determination theory perspective. In K. A., Renninger, S. Hidi, \& A. Krapp (Eds.), The role of interest in learning and development (pp. 43-71). Hillsdale, NJ: Erlbaum.

Deci, E. L., \& Ryan, R. M. (1985). Intrinsic motivation and self-determination in human behavior. New York, NY: Plenum.

DeVon, H. A., Block, M. E., Moyle-Wright, P., Ernst, D. M., Hayden, S. J., Lazzara, D. J., ... Kostas-Polston, E. (2007). A psychometric Toolbox for testing Validity and Reliability. Journal of Nursing Scholarship, 39(2), 155-164.

Didia, D., \& Hasnat, B. (1998). The determinants of performance in the university introductory finance course. Financial Practice and Education, 8(1), 102-107.

Dörnyei, Z. (2001). Motivational strategies in the language classroom. Cambridge, MA: Cambridge University Press.

Dörnyei, Z. (2010). Questionnaires in second language research: Construction, administration, and processing (2nd ed.). London, UK: Routledge.

Dörnyei, Z., \& Otto, I. (1998). Motivation in action: A process model of L2 motivation. Working Papers in Applied Linguistics, 4, 43-69.

Field, A. (2009). Discovering statistics using SPSS ( $3^{\text {rd }}$ ed.). London, UK: Sage.

Finn, A. S., Lee, T., Kraus, A., \& Hudson Kam, C. L. (2014). When it hurts (and helps) to try: The role of effort in language learning. PLoS ONE, 9(7), e101806.

Gao, Z., Podlog, L., \& Harrison, L. (2012). College students' goal orientations, situational motivation and effort/persistence in physical activity. Journal of Teaching in Physical Education, 31, 246-260.

Gardner, R. C. (1985). Social psychology and second language learning: The role of attitudes and motivation. London, UK: Edward Arnold Publishers.

Gardner, R. C. (2001). Integrative motivation and second language acquisition. In Z. Dörnyei \& R. Schmidt (Eds.), Motivation and second language acquisition (pp. 1-19). Hawaii: University of Hawaii Press.

George, D., \& Mallery, P. (2003). SPSS for Windows step by step: A simple guide and reference. 11.0 update (4th ed.). Boston, MA: Allyn \& Bacon.

Ghenghesh, P. (2010a). The motivation of L2 learners: Does it decrease with age? CSSE English Language Teaching, 3(1), 128-141. 
Ghenghesh, P. (2010b). The motivation of learners of Arabic: Does it decrease with age? Journal of Language Teaching and Research, 1(3), 235-249.

Ghiselli, E. E., Campbell, J. P., \& Zedeck, S. (1981). Measurement theory for the behavioral sciences. San Francisco, CA: Freeman \& Company.

Hair, J. F. Jr., Black, W. C., Babin, B. J., Anderson R. E., \& Tatham, R. L. (2006). Multivariate Data Analysis (6th ed.). Upper Saddle River, NJ: Prentice Education, Inc.

Hair, J., Black, W. C., Babin, B. J., \& Anderson, R. E. (2010). Multivariate data analysis (7th ed.). Upper saddle River, NJ: Pearson Education International.

Hair, J., Black, W., Babin, B. J., Anderson, R., \& Tatham, R. (2014). Multivariate data analysis. A global perspective. India: Pearson Prentice Hall.

Heider, F. (1958). The psychology of interpersonal relations. New York, NY: Wiley.

Hinkin, T. R. (1998). A brief tutorial on the development of measures for use in survey questionnaires. Organizational Research Methods, 1(1), 104-124.

Hinkin, T. R. (2005). Scale development principles and practices. In R. A. Swanson \& E. E. Holton (Eds.), Research in organizations: Foundations and methods of inquiry (pp. 161-179). San Fransisco, CA: Berrett-Koehler Press.

Hinkle, D. E., Wiersma, W., \& Jurs, S. G. (2003). Applied statistics for the behavioral sciences (5th ed.). Boston, MA: Houghton Mifflin.

Hsu, S. (2005). Business English learning motivation and effort on proficiency among junior college students. Nanya Education Report, 25, 119-131.

Huang, H. (2015). Can students themselves narrow the socioeconomic-status-based achievement gap through their own persistence and learning time? Education Policy Analysis Archives, 23(108), 1-36.

Huysamen, G. K. (1996). Psychological measurement. An introduction with South African examples. Pretoria: Van Schaik.

Idan, O., \& Margalit, M. (2014). Socioemotional self-perceptions, family climate, and hopeful thinking among students with learning disabilities and typically achieving students from the same classes. Journal of Learning Disabilities, 47(2), 136-152.

Inagaki, Y. (2014). A mediator between motives and learning effort: The role of acquisition goals in motivational process of foreign language learners. Proceeding of the Global Summit on Education GSE, Kuala Lumpur, Malaysia, 455-465.

Jackson, D. L. (2003). Revisiting sample size and number of parameter estimates: Some support for the N: q hypothesis. Structural Equation Modeling, 10(1), 128-141.

Johnson, M. K., Crosnoe, R., \& Elder Jr, G. H. (2001). Students' attachment and academic engagement: The role of race and ethnicity. Sociology of Education, 74(4), 318-340.

Jöreskog, K. G., \& Sörbom, D. (1989). LISREL 7 user's reference guide. Chicago, IL: SPSS Publications.

Jöreskog, K. G., \& Sörbom, D. (1993). Structural equation modeling with the SIMPLIS command language. Chicago, IL: Scientific Software.

Kaiser, H. F. (1974). An index of factorial simplicity. Psychometrika, 39, 31-36.

Kanfer, R. (1992). Work motivation: New directions in theory and research. In C. L. Cooper \& I. T. Robertson (Eds.), International review of industrial and organizational psychology (Vol. 7, pp. 1-53). New York, NY: John Wiley \& Sons.

Kim, J., \& Mueller, C. W. (1978). Factor analysis: Statistical methods and practical issues. Beverly Hills, CA: Sage. 
Kindermann, T. A. (2007). Effects of naturally existing peer groups on changes in academic engagement in a cohort of sixth graders. Child Development, 78(4), 1186-1203.

Kline, P. (1994). An easy guide to factor analysis. New York, NY: Routledge.

Kline, R. B. (1998). Principles and Practice of Structural Equation Modeling. New York, NY: The Guilford Press.

Kline, R. B. (2016). Principles and Practice of Structural Equation Modeling (4th ed.). New York, NY: Guilford.

Kormanik, K. A. (2011). Predictors of student effort and its mediating effects on mathematics achievement (Master's thesis, Stanford University). Retrieved from https://stacks.stanford.edu/ file/druid:pn679ds1629/Kormanik_Katharine_FINAL\%20MA\%20PAPER_2011.pdf

Kuehn, Z., \& Landeras, P (2013). The effect of family background on student effort. Journal of Economic Analysis \& Policy, 14(4), 1337-1403.

Kuh, G. D. (2001). The national survey of student engagement: Conceptual framework and overview of psychometric properties. Bloomington, IN: Indiana University, Center for Postsecondary Research.

Kusurkar, R. A., Ten Cate, T. J., Vos, C. M., Westers, P., \& Croiset, G. (2013). How motivation affects academic performance: A structural equation modelling analysis. Advances in Health Science Education: Theory and Practice, 18(1), 57-69.

Lance, C. E., Butts, M. M., \& Michels, L. C. (2006). The sources of four commonly reported cutoff criteria: What did they really say? Organizational Research Methods, 9, 202-220.

Maroof, D. A. (2012). Statistical methods in neuropsychology: Common procedures made comprehensible. New York, NY: Springer.

Natriello, G., \& McDill, E. (1986). Performance standards, student effort on homework, and academic achievement. Sociology of Education, 59(1), 18-31.

Noels, K. A., Pelletier, L. G., Clément, R., \& Vallerand, R. J. (2000). Why are you learning a second language? Motivational orientations and self-determination theory. Language Learning, 50, 57-85.

Ntoumanis N. (2002). Motivational clusters in a sample of British physical education classes. Psychology of Sport and Exercise, 3, 177-194.

Nunnally, J. C. (1978). Psychometric theory (2nd ed.). New York, NY: McGraw-Hill.

Opare, J. A., \& Dramanu, B. Y. (2002). Students' academic performance: Academic effort as an intervening variable. Ife Psychology, 10(2), 136-148.

Pace, C. R. (1982, May). Achievement and the quality of student effort. Paper presented at the National Commission on Excellence in Education, Washington, DC.

Paris, S. G., \& Turner, J. C. (1994). Situated motivation. In P. R. Pintrich, D. R. Brown \& C. E. Weinstein (Eds.), Student motivation, cognition, and learning: Essays in honor of Wilbert J. McKeachie (pp. 213-237). Hillsdale, NJ: Lawrence Erlbaum.

Pelletier, L. G., Fortier, M. S., Vallerand, R. J., Tuson, K. M., \& Brière, N. M. (1995). Toward a new measure of intrinsic motivation, extrinsic motivation, and amotivation in sports: The sport motivation scale (SMS). Journal of Sport and Exercise Psychology, 17, 35-53.

Pintrich, P. R., Smith, D., Garcia, T., \& McKeachie, W. J. (1993). Reliability and predictive validity of the Motivational Strategies for Learning Questionnaire (MSLQ). Educational and Psychological Measurement, 53, 801-813.

Rau, W., \& Durand, A. (2000). The academic ethic and college grades: Does hard work help students to "make the grade"? Sociology of Education, 73, 19-38. 
Richter, D., Lehrl, S., \& Weinert, S. (2016). Enjoyment of learning and learning effort in primary school: The significance of child individual characteristics and stimulation at home and at preschool. Early Child Development and Care, 186(1), 96-116.

Rosenbaum, R. M. (1972). A dimensional analysis of the causes of the perceived success and Failure (Doctoral dissertation, University of California, Los Angeles). Dissertation Abstracts International, 7310475.

Schau, C., Stevens, J., Dauphinee, T., \& Del Vecchio, A. (1995). The development and validation of the survey of attitudes toward statistics. Educational and Psychological Measurement, 55, 868-875.

Schermelleh-Engel, K., \& Moosbrugger, H. (2003). Evaluating the fit of structural equation models: Tests of significance and descriptive goodness-of-fit measures. Methods of Psychological Research Online, 8(2), 23-74.

Schuman, H. (2001). Comment: Students' efforts and reward in college settings. Sociology of Education, 74(1), 73-74.

Schuman, H., Walsh, E., Olson, C., \& Etheridge, B. (1985). Effort and reward: The assumption that college grades are affected by quantity of study. Social Forces, 63, 945-966.

Shah, P. M., \& Ng, J. M. K. (2005). Acquisition of acrolect Malaysian English at an institution of higher learning. The International Journal of Learning, 12(5), 19-31.

Shah, R., \& Goldstein, S. M. (2006). Use of structural equation modeling in operations management research: Looking back and forward. Journal of Operations Management, 24(2), 148-169.

Shahbaz, M., \& Liu, Y. (2012). Complexity of L2 motivation in an asian ESL setting. Porta Linguarum, 18, 115-131.

Shouse, R., Schneider, B., \& Plank, S. (1992). Teacher assessments of student effort: Effects of race and ethnicity and school type. Educational Policy, 6(3), 266-288.

Soper, J. C. (1976). Second generation research in economic education: Problem of specification and interdependence. Journal of Economic Education, 8(1), 40-48.

Steiger, J. H. (1990). Structural model evaluation and modification: An interval estimation approach. Multivariate Behavioural Research, 25, 173-180.

Stevens, J. (2002). Applied multivariate statistics for the social sciences (4th ed.). Mahwah, NJ: Lawrence Erlbaum.

Tanaka, J. S., \& Huba, G. J. (1984). Confirmatory hierarchical factor analyses of psychological distress measures. Journal of Personality and Social Psychology, 46, 621-635.

Tavakoli, H. (2012). A dictionary of research methodology and statistics in applied linguistics. Tehran, Iran: Rahnama Press.

Terwee, C. B., Bot, S. D., de Boer, M. R., van der Windt, D. A., Knol, D. L., Dekker, J., ... de Vet, H. C. (2007). Quality criteria were proposed for measurement properties of health status questionnaires. Journal of Clinical Epidemiology, 60(1), 34-42.

Trochim, W. M. K. (2001). The research methods knowledge base. Cincinnati: Atomic Dog.

Utami, R. W. (2015). An analysis on students' effort to improve speaking skill. Jurnal Pendidikandan Pembelajaran, 4(3), 1-10.

Weiner, B. (1985). An attributional theory of achievement motivation and emotion. Psychological Review, 92(4), 548-573.

Weiner, B. (1992). Human Motivation: Metaphors, theories and research. Newbury Park, CA: Sage Publications. 
Weiner, B. (2005). Motivation from an attribution perspective and the social psychology of perceived competence. Handbook of competence and motivation, 73-84.

Wolters, C. A. (1999). The relation between high school students' motivational regulation and their use of learning strategies, effort, and classroom performance. Learning and Individual Differences, 11(3), 281-299.

Yeung, A. S. (2011). Student self-concept and effort: Gender and grade differences. Educational Psychology: An International Journal of Experimental Educational Psychology, 31(6), 749-772.

Zimmerman, B. J., \& Risemberg, R. (1997). Self-regulatory dimensions of academic learning and motivation. In G. D. Phye (Ed.), Handbook of academic learning (pp. 105-125). New York, NY: Academic Press.

\section{Appendix 1.}

The Foreign Language Learning Effort Scale (FLLES) with English translations of the items.

\begin{tabular}{|c|c|c|c|c|c|c|}
\hline & & $\begin{array}{l}\text { Hiçbir zaman } \\
\text { (Never) }\end{array}$ & $\begin{array}{l}\text { Nadiren } \\
\text { (Rarely) }\end{array}$ & $\begin{array}{c}\text { Bazı zamanlar } \\
\text { (Sometimes) }\end{array}$ & $\begin{array}{l}\text { Sik sik } \\
(\text { Often })\end{array}$ & $\begin{array}{c}\text { Her zaman } \\
\text { (Always) }\end{array}$ \\
\hline 1. & $\begin{array}{l}\text { Sinavlara iyi hazırlanırım. } \\
\text { (I prepare well for my } \\
\text { foreign language exams.) }\end{array}$ & 1 & 2 & 3 & 4 & 5 \\
\hline 2. & $\begin{array}{l}\text { Derslerde dikkat dağıtıcı } \\
\text { davranışlarda bulunurum. } \\
\text { (I engage in disruptive } \\
\text { behaviors in classes) }\end{array}$ & 1 & 2 & 3 & 4 & 5 \\
\hline 3. & $\begin{array}{l}\text { İşlenen konuları tekrar } \\
\text { ederim. } \\
\text { (I review the topics covered } \\
\text { in my foreign language } \\
\text { class.) }\end{array}$ & 1 & 2 & 3 & 4 & 5 \\
\hline 4. & $\begin{array}{l}\text { Verilen ev ödevlerini } \\
\text { zamanında yaparım. } \\
\text { (I do my homework on } \\
\text { time.) }\end{array}$ & 1 & 2 & 3 & 4 & 5 \\
\hline 5. & $\begin{array}{l}\text { Bir sonraki dersimde } \\
\text { işlenecek konuyu gözden } \\
\text { geçiririm. } \\
\text { (I review the topics to be } \\
\text { covered in my class) }\end{array}$ & 1 & 2 & 3 & 4 & 5 \\
\hline 6. & $\begin{array}{l}\text { Öğretmenimi dikkatli bir } \\
\text { şekilde dinlerim. } \\
\text { (I attentively listen to my } \\
\text { instructor) }\end{array}$ & 1 & 2 & 3 & 4 & 5 \\
\hline 7. & $\begin{array}{l}\text { Ödev verilmese bile çeşitli } \\
\text { kaynaklardan Pratik yaparım. } \\
\text { (Even if I am not given } \\
\text { a homework assignment } \\
\text { I practice from various } \\
\text { sources.) }\end{array}$ & 1 & 2 & 3 & 4 & 5 \\
\hline 8. & $\begin{array}{l}\text { Sinavlarda kopya çekerim. } \\
\text { (I cheat on exams.) }\end{array}$ & 1 & 2 & 3 & 4 & 5 \\
\hline
\end{tabular}




\begin{tabular}{|c|c|c|c|c|c|c|}
\hline 9. & $\begin{array}{l}\text { Yabancı dilde ders dış1 } \\
\text { etkinlikler (örn. kitap } \\
\text { okumak, film izlemek, } \\
\text { yabancılarla konuşmak, vb.) } \\
\text { yaparım. } \\
\text { (I engage in foreign language } \\
\text { mediums in out-of-class } \\
\text { activities (e.g. read books, } \\
\text { watch movies, speak to } \\
\text { foreigners, etc.) }\end{array}$ & 1 & 2 & 3 & 4 & 5 \\
\hline 10. & $\begin{array}{l}\text { Verilen ev ödevlerini } \\
\text { zamanında teslim ederim. } \\
\text { (I submit my homework on } \\
\text { time) }\end{array}$ & 1 & 2 & 3 & 4 & 5 \\
\hline 11. & $\begin{array}{l}\text { Çalışmalarım ile ilgili } \\
\text { düzeltme alırsam, verilen } \\
\text { çalışmadaki eksiklikleri } \\
\text { tamamlarım. } \\
\text { (I revise my assignments if I } \\
\text { receive any corrections) }\end{array}$ & 1 & 2 & 3 & 4 & 5 \\
\hline 12. & $\begin{array}{l}\text { Sınıf arkadaşlarımın derse } \\
\text { yaptıkları katkıları dikkatli } \\
\text { bir şekilde dinlerim. } \\
\text { (I attentively listen to the } \\
\text { contributions made by my } \\
\text { peers) }\end{array}$ & 1 & 2 & 3 & 4 & 5 \\
\hline 13. & $\begin{array}{l}\text { Yabancı dil becerimi nasıl } \\
\text { geliştirebileceğim konusunda } \\
\text { ögretmenime ya da başka } \\
\text { uzmanlara danışırım. } \\
\text { (I consult my foreign } \\
\text { language instructor or other } \\
\text { experts for advice on how to } \\
\text { improve my English) }\end{array}$ & 1 & 2 & 3 & 4 & 5 \\
\hline 14. & $\begin{array}{l}\text { Ödev kopyacıllı̆ı yaparım. } \\
\text { (I plagiarize my homework } \\
\text { assignments) }\end{array}$ & 1 & 2 & 3 & 4 & 5 \\
\hline 15. & $\begin{array}{l}\text { Verildiği takdirde ek ödevler } \\
\text { yapmak için gönüllü olurum. } \\
\text { (If possible, I volunteer } \\
\text { for extra homework } \\
\text { assignments) }\end{array}$ & 1 & 2 & 3 & 4 & 5 \\
\hline 16. & $\begin{array}{l}\text { Verilen sınıf içi çalışmaları } \\
\text { yaparım. } \\
\text { (I carry out the assigned in- } \\
\text { class tasks) }\end{array}$ & 1 & 2 & 3 & 4 & 5 \\
\hline 17. & $\begin{array}{l}\text { Ders sırasında yalnızca derse } \\
\text { odaklanırım. } \\
\text { (I concentrate solely on the } \\
\text { lesson in my classes) }\end{array}$ & 1 & 2 & 3 & 4 & 5 \\
\hline
\end{tabular}

